\title{
THE CONNECTICUT COMPENSATION ACT
}

Connecticut is a proverbially conservative State and rarely has been the first to take up innovations. In adopting an act providing compensation for injured workmen, she has had the advantage of the experience of other countries and other American States. More than three decades ago she took the same course in framing a system of reformed procedure and availed herself of the experiments which had gone before.

The Workmen's Compensation Act will doubtless require and undergo important amendments before it reaches its final form. As it stands now, it represents some of the best features of the system which have proven themselves practical elsewhere, with changes designed to adapt it to Connecticut needs.

The Act went into effect at the beginning of the current year, the commissioners having been appointed three months before and having used the intervening time in determining broad questions of policy, mapping out plans for the administration of the Act and preparing forms, rules and bulletins. The law came as a distinct innovation in Connecticut jurisprudence. It found both the profession and the public unacquainted, not only with its details, but with the underlying conceptions of the system.

The work of those concerned in the administration has been naturally, during the earlier months, largely educational in character, consisting in great part in explaining the Act and seeking to place the people of the State in a position to understand its spirit as well as its details.

The present article is an attempt to give an account of the general features of the Act and the way in which it works; to show what it seeks to accomplish and how the accomplishment is brought about. It is based upon the assumption that while the few may be interested in a critical study of some feature or features of the legislation, the many would be better served by a simple description of what the law is and how it operates, made from the viewpoint of one who has had an opportunity to observe it at close range. In writing it, very free use has been made of material from the pen of the writer of the present article, just published in the national journal devoted to the interests of the compensation systems throughout this country.*

\footnotetext{
*The National Compensation Journal, April, 1914.
} 
The Statute is entitled "An Act Concerning Compensation to Workmen Injured in the Course of Their Employment." The portion of general interest is divided into two parts, the first of which contains general provisions applicable to employers and employees without direct reference to a system of compensation. In brief, this portion of the Act, denominated "Part A", provides that in case of injury to one in the service of an employer with five or more employees the defenses of contributory negligence, fellow-service, and assumption of risk are taken away, leaving those with a less number of employes where they were before the adoption of the Act.

It is elsewhere provided in the Act that any employer may come under the compensation features, in which case his common law liability is at an end. The compensation features of the Act are hence voluntary and it is in the power of every employer to determine whether or not he will exchange an uncertain liability of indefinite extent for a moderate fixed liability, the general opinion in the community being that in the case of employers of five or more it is usually to the direct pecuniary advantage of the employer to accept those features, while in the case of one with a lesser number of employees such adoption involves a pecuniary sacrifice. The practice of the insurance companies is in line with this public opinion, the compensation rates being greater than the common law indemnity rates in the case of employees of less than five men, while they average some twenty per cent. lower in the case of those employing a larger number.

The compensation features being voluntary, both parties to the relation must make either an expressed or implied election. This implied election may be made by simply doing nothing, the law providing that one who does not file a refusal to take advantage of the compensation system is presumed to elect it. Thus far it is only in the exceptional case that either party to the relation has in point of fact filed this refusal, and hence it may be said that the compensation system is in general force throughout the State. In some cases, perhaps out of excess of caution, both parties have declined to come under the compensation system, thus creating an anomalous situation which has not yet come up for formal action.

The law provides a penalty for any attempted evasion of its provisions, and time will undoubtedly disclose instances where pressure has been put upon the employee to decline the Act. The attendant consequences will, of course, have to be determined 
when the instances occur. Cases are said to have occurred where employers have encouraged epileptics and other persons whose health rendered work hazardous, to decline the provisions of the Act. In some cases, at least, this may have been done in good faith, in order to enable the workman to get employment, and an interesting question may arise as to what effect the provision as to evasion has upon this course of conduct.

According to an opinion of the Attorney-General of the State, promulgated before the law went into effect, its provisions affect practically all kinds of service, including farm and domestic labor. The result has been that, as the great majority of farms and the great majority of households employ less than five, a large proportion of the declinations to come within the compensation features of the Act have proceeded from farmers and householders.

Having seen who is affected by the Act, let us turn for a moment to its administration. This is in the hands, not as in some States, of a central Board, but of five Commissioners, each one supreme in his own District, the limits of which coincide with the several Congressional Districts of the State. Each Commissioner maintains an office at some central point where the records are kept and where a large part of the hearings are held. The "Clerk of the Court" is the Secretary of the Commissioner, who is also a trained stenographer, so that whenever occasion requires -and it generally does-the testimony at hearings is taken in full. The jurisdiction of each Commissioner is exclusive and the Board does not sit as a whole to hear cases. In the event of any disqualification or disability, however, one Commissioner may summon in another to sit in his District.

By a wise provision of the law, the Commissioner may sit in any town in his District, the intention being to take the law to the people. At the same time, the practical convenience of holding the sessions at a central point where libraries and other facilities are available, where there is a proper room provided, and where a stenographer is in attendance, are so great that it is believed that practically the Commissioner's office will be found the most convenient to all parties concerned.

While the Board as a whole does not sit as a tribunal, it does perform most important functions. It makes the rules, prescribes the forms and issues the bulletins, and its members meet frequently for the purpose of interchanging views and experiences, 
and trying to keep the rulings and practice in the different Districts uniform so far as possible. Since October first it has not been an infrequent experience for several meetings to be held each week, but probably as the work settles down into regular routine, monthly or bi-monthly meetings will be found sufficient. These meetings are held at the offices of the various Commissioners, and often last far into the night.

The first duty which confronted the Commission was one of the most embarrassing. ones that could be imposed upon any body of administrative officers. A section of the Act provides that an employer, in order to be able to take the benefit, as well as to assume the burden, of the compensation features, shall either furnish a bond to live up to his obligations under the law, insure his risk, or furnish to the Commissioner satisfactory proof of his ability to respond to the obligation to pay compensation. In pursuance of the duty imposed the Commission gave much consideration to the general principles upon which its members should proceed in determining this question of financial ability, and not only sought aid from the inner consciousness and such light as was thrown upon the subject by the experience of similar Boards, but took the opinion of representative business men in all lines in various parts of the State. As a consequence, Bulletin No. 3 was issued, which outlines the guiding principle of the Commission in this respect.

On the one hand, the workman who has lost the right of attachment by mesne process must be protected, and protected as to payments which may extend over a period of ten years. On the other hand, the industries of the State muist not be throttled. The Commission has tried to steer its course between Scylla and Charybdis, and thus far it would seem has met with fair success in its efforts.

The guiding principle determined, the duty of the individual Commissioner begins. In the first place, he makes such investigations as he can into the affairs of the employer, receiving his sworn returns, making outside inquiries and relying also to a considerable extent upon the reports of mercantile agencies to which the various Commissioners are subscribers. It frequently happens that all this requires time, and if a prima facie case is made out, a temporary certificate to run for a month is issued, which may in due time be followed by a certificate for substantially a year. In the case of municipal corporations a blanket cer- 
tificate has been issued by each Commissioner, thus covering all such bodies throughout the State. Where an employer does business in several Districts he must obtain a certificate from each, but by co-operation this entails but little extra work upon either the Commissioner or the employer.

The Attorney-General has ruled that in determining financial ability, insurance in companies not authorized to do business in Connecticut must be disregarded; that while this may be an element in a situation which comes as a whole before the Commissioner, yet, as all questions connected with the subject of insurance are confided not to the Compensation Commissioner but to the Insurance Commissioner, it must have been the intent of the State that no conscious consideration should be given to unauthorized insurance.

Following the analogy of the earlier laws, Connecticut has established a waiting period of two weeks, within which no compensation is due, and, for total incapacity, after that, has prescribed fifty per cent. of the average wages as compensation to be paid during incapacity, but not to exceed five hundred and twenty weeks. In the case of certain specified injuries, principally in the limbs, the number of weeks' compensation is fixed arbitrarily. In the case of death, compensation may be due for three hundred and twelve weeks. The minimum compensation is five dollars a week and the maximum is ten dollars a week. In the case of partial incapacity the injured person is entitled to onehalf of the difference between what he is able to earn and what he would normally earn. In case of total dependents, the whole compensation is paid; in case of partial dependents, a proportionate part.

An interesting question which has been tried out and argued before one of the Commissioners, but not yet decided, arises in a case where two phalanges were amputated from each of two fingers, and one phalanx from another finger-the fore-finger. The employer contends that the greater includes the less, and that the compensation should be the same as though two phalanges had been amputated from each of the three fingers, the number of weeks figuring out, according to the table, forty-six and a half. The contention of the injured is that the case does not come squarely within the terms of the "phalanx" provision and that therefore the incapacity is to be determined in the same way as though the injury was one where there was no arbitrary number of weeks involved. 
The hearings are conducted very informally. No pleadings are required, although they may be filed voluntarily for the purpose of presenting the issue squarely. If filed, however, the technical rules of the law of pleading do not apply. The Commissioner is not held down to formal rules of evidence, and applies only those principles which 'are inherent in any plan or scheme of getting at the truth. There are no costs, although each party must furnish his own witnesses and pay for any copies of the stenographic record that he may desire.

The formal hearings, however, have been very few in number. The informal hearings, where the parties have come before the Commissioner with some little difficulty which could be smoothed away, or desirous of getting the proper results but not knowing just how to do it, have been very numerous indeed. The Commissioners have taken the view that while they are in a sense judicial officers and should preserve judicial reserve in essentials where rights have become fixed and may come before them for adjudication, yet, as pioneers in the administration of a system entirely new to the State, it is a part of their duty to aid those within the purview of the law to understand it. They have, therefore freely given tentative opinions. In doing so, however, they have ever striven not only to keep the mind open for the formal decision where it has to be given, but to impress upon those who sought their impressions informally that their attitude was that so aptly expressed in Arnold Bennett's "Those United States""As for these brief chapters, I hereby announce that I am not prepared ultimately to stand by any single view which they put forward. There is naught in them which is not liable to be recanted."

The procedure where an injury has occurred is simple. The employee gives notice to his employer that he has been hurt and claims compensation. The lack of such notice is only fatal to his recovery where the employer is in the dark and has been hopelessly prejudiced. Whether he receive this notice or not, the employer must report the injury to the Commissioner. If the parties get together on a voluntary agreement it comes before the Commissioner for approval, and in ninety-five per cent. of the cases this marks the ultimate disposition of the case. If they do not agree, either side may ask for a hearing.

The voluntary agreement is not a compromise but an agreement as to facts and as to what should be paid. Both agreements and 
awards are filed in the Superior Court, and have the effect of judgments upon which execution can be issued by the Clerk of the Court. From these awards there is an appeal to the Superior Court, and one of the interesting points which must speedily be decided is as to the scope of the jurisdiction of the Superior Court on appeal, as to whether there will be a hearing 'de novo' or whether the Court will refuse to review the conclusions of fact reached by the Commisioner.

In the administration of the law, unsettled points are arising hourly. Does it apply to employees working out of the State, or. is its operation confined to work in Connecticut? Just what is a casual employee? What is the "serious and willful misconduct" which will deprive one of his rights under the Act? These and countless other queries present themselves, some involving clean cut questions of law, and some mixed questions of law and fact, the answers to which must vary as the facts shift in kaleidoscopic movement.

The statistics for the first two months are now available. The total number of injuries reported for January and February was 2,810 , the Third District, the largest in population, leading in this unfortunate procession with 693. Formal claims had been made in 330 cases. Two hundred and fifty-seven agreements had been approved. There had been 25 deaths, and four death settlements. The statistics as to hearings during March are not yet available, but they present a radically different situation from those of January and February, during which there had been only a single formal hearing throughout the whole State.

It is an opinion frequently expressed by the Commissioners that voluntary agreements and informal hearings should be encouraged, as they not only save trouble and expense to the interested parties, which in many cases can be ill afforded, but tend to substantial justice and leave a pleasanter taste in the mouth.

The informal character of the hearings is illustrated by one recently held in the New Haven District. The employee, who was not much of a scholar, could not seem to get it into his head that there was a waiting period, or understand why he should not get his full pay. Furthermore, he had no idea how irregular his employment had been, and unconsciously exaggerated his earnings. He had obviously every disposition to be fair, but did not know how to get about it. He came before the Commissioner, and the representative of his employer came also. Some two hours were 
spent in straightening the thing out, and at the end both parties left with an award satisfactory to both sides. The contrast between a hearing of this kind and an ordinary law suit is obvious. Lawsuits have their place, but they are after all a little like war, and should not loom too large in the daily life of the community.

The attitude of the Commissioners towards the legal profession may be expressed about as follows: They do not believe that sound public policy should require in a simple case the absorption of a considerable amount of the compensation in legal fees. They recognize the fact that the average accident presents a simple question which the parties can handle themselves with the aid of the Commissioner, and this course should be pursued. They recognize, however, the right of the parties to have counsel in any case, and in cases involving difficult questions of law and fact, and considerable amounts, they believe that injured parties and employers both are entitled to have all the light that can be secured, and that not only may the interests of the employer require expert assistance, but that it may be as unwise for an injured employee to try to handle-his own claim for compensation as to attempt to heal his physical ills without a doctor.

The relation of the lawyer to the compensation law is protected from abuse in that the Commissioner must pass upon the fees, and it must be said in justice to those concerned that in the few cases which have come up for determination involving this subject of fees, the charges have been exceedingly fair and moderate. In the same way, the amount of physicians' fees is within the jurisdiction of the Commissioner.

In all human transactions there will always be questions for the lawyer and controversies in which he is a vital element. As long as language is used, ambiguities will exist. Wherever there is an important controversy, those whose rights are involved cannot afford to avail themselves of the services of those experienced in preparation and in trial. The expense of professional assistance, however, must not bear on the average too great a proportion to the amount in controversy. It would be a reproach to any system providing for the sharing by the employer of losses, falling, in the first instance upon the employee, that it should entail any such percentage of expense as that familiar in the ordinary suit for personal injury. The system should be largely automatic and should be so administered that professional assistance should be 
unnecessary in cases involving trifling amounts and should be minimized in larger controversies.

A high officer of the State is quoted as saying that any old woman with a shawl over her head should be able to approach the Commissioner and get justice. Whether this terse description was actually given or not, it aptly expresses a truth and involves the high conception of a tribunal which seeks to do justice without unnecessary formality and which, while welcoming the highest grade of professional assistance, has the great privilege of guarding the interests of those who have no other protector.

\section{New Haven.}

George E. Beers. 